Proceedings

\title{
Conditions of Urban Green Areas Influences Bee Guilds Responses ${ }^{\dagger}$
}

\author{
Sônia Guimarães Alves * and Maria Cristina Gaglianone
}

Citation: Alves, S.G.; Gaglianone, M.C. Conditions of Urban Green Areas Influences Bee Guilds Responses. Proceedings 2021, 68, $\mathrm{x}$ https://doi.org/10.3390/xxxxx

Published: date

Publisher's Note: MDPI stays neutral with regard to jurisdictional claims in published maps and institutional affiliations.

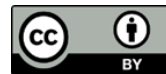

Copyright: (C) 2021 by the authors. Submitted for possible open access publication under the terms and conditions of the Creative Commons Attribution (CC BY) license (http://creativecommons.org/licenses /by/4.0/).
CBB, Laboratório de Ciências Ambientais, PPG-Ecologia e Recursos Naturais, Avenida Alberto Lamego 2000, Campos dos Goytacazes, Universidade Estadual do Norte Fluminense Darcy Ribeiro, RJ, Brazil; email1@com

* Correspondence: soniagui68@gmail.com; Tel.: 55-(22)-99800-1578

† Presented at the 1st International Electronic Conference on Biological Diversity, Ecology and Evolution, 1531 March 2021; Available online: https://bdee2021.sciforum.net/.

\begin{abstract}
The deforestation consequent of urban sprawl is one of the causes of decline of wild bee communities and the urban green areas (UGA) can be important refuges for bees. This study analyzed the influence of UGA conditions and their surroundings in bee guilds responses in a mediumsized Brazilian city (Campos dos Goytacazes, RJ). The bees were sampled for 12 months (2017-2018) in 12 UGAs; bee abundance and richness were evaluated in guilds considering: sociality (eusocial, intermediate and solitary), nesting (cavity and soil) and foraging (generalist and specialist). We used as explanatory variables conditions of UGAs - number of trees (NT), DBH, flower cover (FC), plant richness (PR), percentage of paving (PV) - and of their surroundings - paving (SPV) and number of buildings (NB). Results showed $80 \%$ of eussocial and generalist bees and $13 \%$ solitary; $82 \%$ nest in cavities and $20 \%$ were specialists. From all explanatory variables PV, NB, FC and SPV explained the responses of different guilds in study areas. This study confirms different responses by the guilds analysed. In order to conserve bee diversity, the management of UGAs must consider the abundance and richness of flowers, maintenance of exposed soil areas and the density of trees.
\end{abstract}

Keywords: conservation; environmental management; pollinators; urban spraw

\section{Introduction}

The UN estimates that the urban population will exceed $60 \%$ by the year 2050 . The changes resulting from this growth affect mainly medium-sized cities (between 500 thousand and one million inhabitants) where half of the world's urban population currently lives. The great challenge for these cities is the sustainable growth that guarantees housing transport system and energy for population, combined with environment preservation and conservation of biodiversity [1]. The urbanization process causes drastic changes in the landscape, often irreversible, such as the increase of impervious areas(pavement, asphalt, buildings) and the destruction of natural areas [2]. Studies carried out around the world show that the expansion of urban areas is identified as one of the main causes for the decline of pollinators [3-5]. The destruction of natural areas means for pollinators the loss of nesting and foraging sites. the isolation of populations and interruption of ecological interactions [6]. Among the affected pollinators are all bee species (Hymenoptera. Apoidea). Which are considered important for the pollination of most species of native. exotic and cultivated plants [7]. The bees loss has the direct consequence of losing several plant species [8].

In this context, urban green areas such as squares, parks, forests and gardens can be bee-friendly spaces $[9,10]$ with potencial to act like refuge for bees, with foraging and nesting conditions $[4,11,12]$. In other to this occour. It is necessary to manage these areas considering the different biological and functional bee traits as their nesting habit. Degree of sociality and specialization or generalization regarding the choice of resources [13-15]. 
Grouping bees in guilds can provide data that increase the efficiency of management and conservation of bees and plants species [16]. However, little is known about how the different bee guilds respond to conditions found in urban areas [13]. Thus, knowing how bee communities are structured and how the conditions of urban green areas and their surroundings influence this structure can contribute to the management and strategies for preserving biodiversity. Therefore. this work aims to answer the following questions: (1) What is the community structure found in urban green areas associated to a mediumsized city in Brazil?; (2) What are the environmental conditions of urban green areas and their surroundings?; (3) How do the different bee guilds respond to the conditions of urban green areas?

\section{Materials and Methods}

\subsection{Study Area}

This study was conducted in Campos dos Goytacazes. RJ. Brazil. the largest municipality in the interior of Rio de Janeiro state with approximately $4.037 \mathrm{~km}^{2}$ and an urban area of $87.73 \mathrm{~km}^{2}$. The total population is 507.548 thousand inhabitants and almost $85 \%$ of population lives in the urban area [17]. The climate is hot and humid tropical AW (Köppen-Geiger classification), with dry winter (April to September) and rainy summer (October to March); average annual rainfall between 800 and $1200 \mathrm{~mm}$ [18]. The average temperature is around $26^{\circ} \mathrm{C}$ in the hottest months and $19{ }^{\circ} \mathrm{C}$ in the coldest ones.

\subsection{Bee Sampling}

We sampled the bees with entomological net in the 12 UGAs between October 2017 and September 2018, twice in the rainy season and twice in the dry season at each UGA. Sampling at each site was carried out by two collectors, who walked along the 12 UGAs in search of flowers in three periods of about one hour each, between 7 am and $1 \mathrm{pm}$, and visiting bees were captured. Bee species were identified and deposited at UENF Zoological Collection. They were classified by: (1) Nest location (soil or pre-existing cavity); (2) Nesting behavior (solitary, intermediate, eussocial); (3) Trophic specialization (generalist, specialist), according to the literature.

\subsection{Environmental Conditions}

In order to determine which variables influence the richness and abundance of species in the UGAs, we measured: paved area, richness of plants visited by bees, flower coverage, number of trees, $\mathrm{DBH}$ of trees with more than $30 \mathrm{~cm}$ in circumference and total impervious area. The identification of the plant species where the bees were captured was done with the help of specialized literature [20,21] and the Flora Brasil project [22]. Flower coverage was estimated for all flowering species on the days of bees sampling, through percentage covered by flowers related to the total area occupied by the plants. The average percentage of the four sampling days was considered as an estimate of flower coverage for each sample area. The areas of pavedsoil were measured using the Google Earth polygon tool.

For the analysis of the conditions found around the AVUs. The variables paved area and number of buildings with more than three floors were considered. These variables were measured within a $500 \mathrm{~m}$ radius (buffers) from the center of each of the 12 AVUs $[23,24]$. The paved area inside each buffer was measured with the polygon tool and the count of buildings with more than three floors was done with street view. Both tools from Google Earth Pro (2019).

\subsection{Data Analysis}

We tested the effects of environmental variables (predictors: paved area, DBH of trees, plant richness, flower coverage, paved area around and number of buildings with more than three paviments) on species richness and abundance using multivariate generalised 
linear models (GLMs). We tested the collinearity between the predictors variables using the variance inflation factor (vif) of the car package. The best model was selected using the lowest value of Akaike information criterion (AIC). These analyzes were performed using the R version 3.5.1 program. assuming a 95\% significance level [25].

\section{Results}

\subsection{Bee Community}

In total, 1163 individuals were collected. Apidae was the family with the greatest richness (19species) and abundance (991 individuals). The tribes with the greatest species richness were Augochlorini (13) and Meliponini (5). The most abundant species were Apis mellifera (32\% of individuals sampled), Trigona spinipes (26\%) and Plebeia droryana (13\%), all eusocial species. Among the non-eusocial species, the most abundant were Dialictus sp1 (4\%). Augochlora thalia (3\%) and Xylocopa frontalis (2\%). Of the individuals sampled, $80 \%$ showed eusocial behavior, $13 \%$ belong to solitary bee species and $5 \%$ bees of species with intermediate level of sociality. Bees that nest in pre-existing cavities represented $82 \%$ of the bees collected. In addition, $80 \%$ of bee species were generalists in the foraging habit and $20 \%$ specialists.

\subsection{Environmental Conditions}

Six studied UGAs presented more than $50 \%$ of their inside area paved and only one of the 12 UGAs had less than $50 \%$ of the surround area paved. The average of flower coverage in each UGA varied between $6.57 \mathrm{~m}^{2}(\mathrm{U} 4)$ and $82.52 \mathrm{~m}^{2}(\mathrm{U} 7)$. The largest number of trees was registered at the U11 and the highest DBH (median $=63$ ) at the U7 sample unit. Three of the 12 areas studied did not have buildings with more than three floors (Table 1).

Table 1. Environmental conditions of 12 urban green areas (UGA) studied in Campos dos Goytacazes/RJ. Inside UGA: percentage of paving (PV), number of trees (NT), diameter in breast height (DBH), plant richness (PR), flower coverage in $\mathrm{m}^{2}$ (FC). Surround conditions measured inside a buffer of 500m from UGA center: surround percentage of paving (SPV) and number of buildings with more than three paviments (NB).

\begin{tabular}{|c|c|c|c|c|c|c|c|c|c|c|c|c|}
\hline \multirow[b]{2}{*}{ Conditions } & \multicolumn{12}{|c|}{ Urban Green Areas } \\
\hline & U1 & U2 & U3 & $\mathrm{U} 4$ & U5 & U6 & U7 & U8 & U9 & U10 & U11 & U12 \\
\hline & 61.3 & 92.5 & 50.4 & 37.3 & 35.9 & 27.8 & 0 & 63.0 & 90.3 & 19.4 & 8.7 & 70.9 \\
\hline NT & 34 & 36 & 33 & 22 & 46 & 78 & 22 & 33 & 15 & 63 & 369 & 17 \\
\hline $\mathrm{DBH}$ & 23 & 27 & 16 & 22 & 26 & 35 & 63 & 30 & 53 & 22 & 32 & 32 \\
\hline PR & 13 & 11 & 12 & 6 & 13 & 14 & 17 & 9 & 10 & 14 & 18 & 14 \\
\hline $\mathrm{FC}$ & 60.8 & 47.5 & 10.6 & 6.5 & 42.6 & 33.7 & 82.5 & 22 & 22.7 & 26.7 & 21.3 & 11.7 \\
\hline SPV & 63 & 96 & 87 & 71 & 92 & 97 & 45 & 51 & 72 & 84 & 75 & 89 \\
\hline NB & 12 & 0 & 11 & 14 & 60 & 37 & 4 & 0 & 8 & 0 & 7 & 10 \\
\hline
\end{tabular}

\subsection{Data Analysis}

Flower coverage was the predictor variable that influenced five of the guilds analyzed in this study. The percentage of paving and the number of buildings with more than three floors explained the abundance and richness of solitary bees, respectively. The DBH had a negative effect on the abundance of specialist bees and the richness of solitary and generalist bees, presenting a positive result only for the richness of eussocial bees (Table 2). 
Table 2. Parameter estimates of a generalized linear model, assessed as most parsimonious according to AIC, explaining abundance and richnees of bee guilds in urban green area (UGA) in Campos dos Goytacazes/RJ. Inside UGA: percentage of paving (PV), number of trees (NT), diameter in breast height (DBH), plant richness (PR), flower cover in $\mathrm{m}^{2}(\mathrm{FC})$. Surround conditions measured inside a buffer of $500 \mathrm{~m}$ from UGA center: surround percentage of paving (SPV) and number of buildings with more than three paviments (NB).

\begin{tabular}{|c|c|c|c|c|c|c|c|c|c|c|c|c|c|c|}
\hline \multirow{2}{*}{$\begin{array}{c}\text { Variables } \\
\text { Abundance }\end{array}$} & \multirow[t]{2}{*}{ Model } & \multirow[t]{2}{*}{ NT } & \multirow[t]{2}{*}{ FC } & \multirow[t]{2}{*}{ DBH } & \multirow[t]{2}{*}{ PR } & \multirow[t]{2}{*}{ PV } & \multirow[t]{2}{*}{ SPV } & \multirow[t]{2}{*}{ NB } & \multirow[t]{2}{*}{ Intercept } & \multirow[t]{2}{*}{ df } & \multirow[t]{2}{*}{ AICc } & \multicolumn{2}{|c|}{$\Delta$ AICc Weight } & \multirow[t]{2}{*}{$\overline{A d j R} R^{2}$} \\
\hline & & & & & & & & & & & & & & \\
\hline Eusocial & 5 & & 1.079 & & & & & & 40.42 & 3 & 126.5 & 0 & 0.191 & 0.341 \\
\hline $\begin{array}{c}\text { Intermediat } \\
\mathrm{e}\end{array}$ & 5 & & 0.109 & & & & & & 2.188 & 3 & 66.8 & 0 & 0.396 & 0.438 \\
\hline Solitary & 17 & & & & & 0.143 & & & 9.282 & 3 & 96 & 1.51 & 0.164 & 0.110 \\
\hline Soil & 33 & & & & & & 0.374 & & 43.88 & 3 & 92.2 & 0 & 0.438 & 0.386 \\
\hline Cavity & 5 & & 1.162 & & & & & & 44.16 & 3 & 127.3 & 0 & 0.263 & 0.359 \\
\hline Specialist & 13 & & 0.106 & -0.157 & & & & & 3.221 & 4 & 68.7 & 1.04 & 0.149 & 0.461 \\
\hline Generalist & 5 & & 1.235 & & & & & & 55.28 & 3 & 126.7 & 0 & 0.279 & 0.399 \\
\hline Richness & & & & & & & & & & & & & & \\
\hline Eusocial & 33 & & & 0.05 & & & 0.039 & 0.034 & -1.938 & 5 & 34.5 & 0 & 0.334 & 0.876 \\
\hline $\begin{array}{c}\text { Intermediat } \\
\mathrm{e}\end{array}$ & 5 & & 0.089 & & & & & & 1.618 & 3 & 51.1 & 0 & 0.276 & 0.333 \\
\hline Solitary & 73 & & & -0.108 & & & & 0.076 & 9.827 & 4 & 61.4 & 0.1 & 0.152 & 0.50 \\
\hline Soil & 5 & & 0.045 & & & & & & 1.618 & 3 & 51.1 & 0 & 0.276 & 0.333 \\
\hline Cavity & 3 & $\begin{array}{c}0.01 \\
37\end{array}$ & & & & & & & 4.537 & 3 & 59.4 & 0 & 0.121 & 0.300 \\
\hline Specialist & 5 & & 0.013 & & & & & & 0.125 & 3 & 37.7 & 2.2 & 0.083 & 0.461 \\
\hline Generalist & 9 & & & -0.065 & & & & & 12.65 & 3 & 66.2 & 2.48 & 0.082 & 0.094 \\
\hline
\end{tabular}

\section{Discussion}

The results of this study demonstrated that the study area is in a high level of urbanization with percentages of paving above $50 \%$ [26] and urban densification, despite being a medium-sized city. At this stage the natural areas have already been replaced by large paved areas, where only low flower covers and potential nesting places for bees remain. Making this areas harmful to the pollinator community [4].

Results indicated that the different guilds of bees diverged in responses to the conditions found in urban green areas and their surroundings. The structure of the bee community showed a composition mainly of eusocial and generalist bees, common in open and highly modified environments. Other studies carried out in Brazil have shown the tendency for eusocial bees to be more abundant in urban areas [42-45]. These results can be explained by the fact that the colonies of eusocial species have thousands of individuals and are active throughout the year, which allows to take advantage of resources from plant species with different phenological cycles [7]. In addition, eusocial bees recrute and are able to collect a large amount of resources quickly. In places with little diversity of resources, these eusocial bees are usually benefited when compared to solitary bees.

The greater plasticity of $A$. mellifera favors the increase of its abundance in urban areas and the competitive pressure on native species, which can lead to the homogenization of the structure of the bee community in these areas [31] through the replacement of native bee species by this exotic one [32]. Although several human activities promote biotic homogenization. Urbanization is the one that most favors this process $[33,34]$. The city is made to atend human needs and therefore has a uniform nature, which is repeated throughout the world with buildings, roads and houses. The construction of cities destroys the habitat of native species. But on the other hand creates habitat for other exotic species such as $A$. mellifera. As a consequence. More vulnerable species tend to disappear. Decreasing the community species richness $[33,34]$. 
Among the guilds that demonstrate greater vulnerability to the urban environment are the specialist bees, In this study, specialists represented only $20 \%$ of the community, similar to described by other studies that recorded low abundance of specialist bees in the urban area [26]. One of the reasons why specialists bees are less recorded is the substitution of native vegetation by exotic plants. This is a pattern of anthropized environments. Limiting the availability of resources $[15,35]$. The decline of specialist bees is directly related to the loss of the host plant, as described in study that found the decline of specialist bees associated with the decline of Fabaceae plants caused by the management of agricultural areas and removal of native vegetation [36]. Other studies showed that the dominance of generalist bee species increases competition over resources, contributing to the change in the behavior of specialist bees in the face of resource scarcity [37]. This change in behavior explains the influence of the variable "flower coverage" on the richness and abundance of specialist bees found in this study; greater flower coverage decreases competition and increases the possibility of foraging. The best predictor model for the abundance of specialist bees also showed a negative relationship with DBH. Whereas trees with a higher DBH are also trees with a higher canopy, which increase the shading and limit the growth of other plants that could serve as a resource for specialist bees. A similar result was described by [38] when observing a correlation between the decrease in species of oligolytic bees and the increase in canopy coverage.

Analyzing the abundance of bees that nest in the soil we found a sensitivity related to the "surroundings percentage paving". Of the 41 species of bees sampled in this study. Only $18 \%$ are from the guild that nests in the soil. As the paving of the surroundings increases. There is less abundance of bees from this guild in the UGAs. The negative influence of paving on this bee guild is due to the limited nesting site consequence of replacement of exposed soil areas by paved areas in UGAs and surroundings, as well as the removal of small bushes or spontaneous vegetation that provide food resources [27]. However. For bees that nest in the soil. The availability of nest building sites may be more important in the establishment and growth of their populations than the availability of food resources $[10,13]$.

A lower abundance of solitary bees was found overall. Only $13 \%$ of the captured bees belonged to solitary species. The statistical analysis showed the influence of the variable "percentage paving" on solitary bees abundance and the variable "number of buildings with more than three floors" on richness. The urban environment is composed of mosaics of vegetation and buildings [39] that probably prevent or hinder the circulation of bees with a small flight radius like many solitary bees [40]. Few individuals in this group reach long flight ranges. Which increases the dependence of solitary bees on the resources available near the nests. The distance from the resource determines the ability to maintain the species as verified by [39]. According to the authors. The number of descendants generated by the species Osmia lignaria was greater when the nest was close to areas with greater supply of resources. We can expected similar situation for solitary bees in studied areas. Considering the cost of foraging trips is critical for solitary bee guild conservation programs including the management in urban areas.

\section{Conclusions}

We suggest that decisions about management of urban green areas must be a transdisciplinary decision making and planning. The management of urban green areas is complex and needs to take into account many factors, such as acclimatization and adaptation of species to urban devices. However, it is also necessary to pay attention to factors that contributes to minimize the negative effects of urbanization on the bee community to find nesting places, foraging and feeding needs. Bee conservation programs in urban areas should include the management of plants that provide resources for bees and other pollinators. The increase of impervious surfaces must be avoided, because in addition to not being beneficial to bees, which do not find resources and place to make their nests, it causes local heating. The creation and maintenance of urban parks with more vegetation 
cover is important to maintain the milder climate and increase the diversity of important animals, such as pollinators and seed dispersers in the urban area. This vision is pursued within two of the UN Sustainable Development Goals (SDGs), item 15, which deals with terrestrial Life and aims to protect, recover and promote the sustainable use of terrestrial ecosystems, sustainably manage forests, combat desertification, stop and reverse the degradation of the Earth and stop the loss of biodiversity. And item 11 that deals with Cities and sustainable communities with the objective of making cities and human settlements inclusive, safe, resilient and sustainable. This work considers that the planned urban policies, considering other organisms besides humam beings, can lessen the negative impacts of rapid urbanization. A new way of looking at the city, one that considers man as part of the ecosystem and that by conserving other species will be conserving its quality of life in the urban environment.

\section{Author Contributions:}

\section{Funding:}

\section{Institutional Review Board Statement:}

\section{Informed Consent Statement:}

\section{Data Availability Statement:}

Acknowledgments: We thank the graduation Program of Ecology and Natural Resources from Universidade Estadual do Norte Fluminense Darcy Ribeiro. This work was carried out with the support of the Coordenação de Aperfeiçoamento de Pessoal de Nível Superior-Brazil (CAPES). from where SGA receives grant (Capes -88887.466928/2019-00). MCG thanks to CNPq (303894/2018-0) and FAPERJ (203.321/2017) for financial support.

Conflicts of Interest: The authors declare no conflict of interest.

\section{References}

1. United Nations, Department of Economic and Social Affairs, Population Division. World Population Prospects 2019: Press Release; ST/ESA/SER.A/352; New York, NY, USA, 2018; 27p. Available online: https://www.un.org/development/desa/en/news/population/2018-revision-of-world-urbanization-prospects.html (accessed on 13 April 2020).

2. McKinney, M.L. Urbanization, biodiversity, and conservation. Bioscience 2002, 52, 883-8902. doi:10.1641/00063568052[0883:UBAC]2.0.CO;2.

3. Vanbergen, A.J.; Garratt, M.P. The Insect Pollinators Initiative Threats to an ecosystem service: Pressures on pollinators. Front. Ecol. Environ. 2013, 11, 251-259. doi:10.1890/120126.

4. Fortel, L.; Henry, M.; Guilbaud, L.; Guirao, A.L.; Kuhlmann, M.; Mouret, H.; Vaissière, B.E. Decreasing abundance, increasing diversity and changing structure of the wild bee community (Hymenoptera: Anthophila) along an urbanization gradient. PLoS ONE 2014, 9, e104679. doi:10.1371/journal.pone.0104679.

5. Ollerton, J.; Erenler, H.; Edwards, M.; Crockett, R. Extinctions of Aculeate pollinators in Britain and the role of large-scale agricultural changes. Science 2014, 346, 1360-1362. doi:10.1126/science.1257259.

6. Fischer, J.; Lindenmayer, D.B. Landscape modification and habitat fragmentation: A synthesis. Glob. Ecol. Biogeogr. 2007, 16, 265-280. doi:10.1111/j.1466-8238.2007.00287.x.

7. Michener, C.D. The Bees of the World, 2nd ed.; Johns Hopkins University: Baltimore,MD, USA, 2007; 953p.

8. Winfree, R.; Aguilar, R.; Vázquez, D.P.; Lebuhn, G.; Aizen, M.A. A meta-analysis of bees' responses to anthropogenic disturbance. Ecology 2009, 90, 2068-2076. doi:10.1890/08-1245.1.

9. McFrederick, Q.S.; LeBuhn, G. Are urban parks refuges for bumble bees Bombus spp. (Hymenoptera: Apidae)? Biol. Conserv. 2006, 129, 372-382. doi.org/10.1016/j.biocon.2005.11.004.

10. Senapathi, D.; Goddard, M.A.; Kunin, W.E.; Baldock, K.C.R. Landscape impacts on pollinator communities in temperate systems: Evidence and knowledge gaps. Funct. Ecol. 2017, 31, 26-37. doi:10.1111/1365-2435.12809.

11. Banaszak-Cibicka, W.; Żmihorski, M. Wild bees along a urban gradient: Winner sand losers. J. Insect Conserv. 2012, 16, 331-343. doi:10.1007/s10841-011- 9419-2.

12. Levé, M.; Baudry, E.; Bessa-Gomes, C. Domestic gardens as favorable pollinator habitats in impervious landscapes. Sci. Total Environ. 2019, 647, 420-430. doi:10.1016/j.scitotenv.2018.07.310.

13. Threlfall, C.G.; Walker, K.; Williams, N.S.G.; Hahs, A.K.; Mata, L.; Stork, N.; Livesley, S.J. The conservation value of urban green space habitats for Australian native bee communities. Biol. Conserv. 2015, 187, 240-248. doi:10.1016/j.biocon.2015. 05.003.

14. Roubik, D.W. Ecology and Natural History of the Tropical Bees; Cambridge University: New York, NY, USA, 1989; 514p. 
15. Cane, J.H.; Sipes, S. Characterizing floral specialization by bees: Analytical methods and a revised lexicon for oligolecty. In Plant-Pollinator Interactions: From Specialization to Generalization; Waser, N.M., Ollerton, J., Eds.; University of Chicago Press: Chicago, IL, USA, 2006; 99-122p.

16. Normandin, É.; Vereecken, N.J.; Buddle, C.M.; Fournier, V. Taxonomic and functional trait diversity of wild bees in different urban settings. PeerJ 2017, 5, e3051,doi:10.7717/peerj.3051.

17. Instituto Brasileiro de Geografia e Estatística. IBGE. Available online: http://ibge.gov.br (accessed on 20 May 2020).

18. Köppen, W.;Geiger, R. Klimate der Erde; Wall-Map 150 cm × 200 cm;Verlag Justus Perthes: Gotha, Germany, 1928.

19. Martins, A.C.; Goncalves, R.B. Melo, Ga RChanges in wild bee fauna of a grassland in Brazil reveal negative effects associated with growing urbanization during the last 40 years. Zoologia 2013, 30, 157-176, doi:10.1590/S1984- 46702013000200006.

20. Lorenzi, H. Árvores Brasileiras: Manual de Identificação e Cultivo de Plantas Arbóreas Nativas do Brasil, 2nd ed.; Editora Plantarum: Nova Odessa, SP, Brasil, 1992; Volume 1, 384p.

21. Lorenzi, H. Árvores Brasileiras: Manual de Identificação e Cultivo de Plantas Arbóreas Nativas do Brasil, 2nd ed.; Editora Plantarum: Nova Odessa, SP, Brasil, 2002; Volume 2, 368p.

22. FloraBrasil. 2019. Available online: http://floradobrasil.jbrj.gov.br/ (accessed on 15 April 2020).

23. Makinson, J.M.; Threlfall, C.G.; Latty, T. Bee-friendly community gardens: Impact of environmental variables on the richness and abundance of exotic and native bees. Urban Ecosyst. 2017, 20, 463-476. doi:10.1007/s11252-016-0607-4.

24. Plascencia, M.; Philpott, S.M. Floral abundance, richness, and spatial distribution drive urban garden bee communities. Bull. Entomol. Res. 2017, 107, 658-667. doi:10.1017/S0007485317000153.

25. R Development Core Team. R: A Language and Environment for Statistical Computing; R Foundation for Statistical Computing: Vienna, Austria, 2019. Available online: http://www.R-project.org (acessed on 25 March 2020).

26. Wenzel, A.; Grass, I.; Belavadi, V.V.; Tscharntke, T. How urbanization is driving pollinator diversity and pollination -A systematic review. Biol. Conserv. 2020, 241, 108321 doi:10.1016/j.biocon.2019.108321.

27. Taura, H.M.; Laroca, S. A associação de abelhas silvestres de um biótopo urbano de Curitiba (Brasil), com comparações espaço temporais: Abundância relativa, fenologia, diversidade e exploração de recursos. Acta Biol. Parana. 2001, 30, 135-137. doi:10.5380/abpr.v30i0.599.

28. Zanette, L.R.S.; Martins, R.P.; Ribeiro, S.P. Effects of urbanization on neotropical wasp and bee assemblages in a Brazilian metropolis. Landsc. Urban Plan. 2005, 71, 105-121. doi:10.1016/j.landurbplan.2004.02.003.

29. Taura, H.M.; Laroca, S.; Barbosa, J.F.;Rodrigues, J. Melissocenótica (Hymenoptera, Anthophila) no Parque Florestal dos Pioneiros, Maringá, PR. (sul do Brasil). Acta Biol. Parana. 2007, 36, 47-65. doi:10.5380/abpr.v36i0.9658.

30. Cardoso, M.C.; Gonçalves, R.B. Reduction by half: The impact on bees of 34 years of urbanization. Urban Ecosyst. 2018, 21, 943949. doi:10.1007/s11252-018-0773-7.

31. McKinney, M.L. Urbanization as a major cause of biotic homogenization. Biol. Conserv. 2006, 127, 247-260.doi:10.1016/j.biocon.2005.09.005.

32. McKinney, M.L.; Lockwood, J.L. Biotic homogenization: A few winners replacing many losers in the next mass extinction. Trends Ecol. Evol. 1999, 14, 450-453. doi:10.1016/s0169-534701679-1.

33. McKinney, M.L.Do exotics homogenize or differentiate communities? Roles of sampling and exotic species richness. Biol. Invasions 2004, 6, 495-504. doi:10.1023/B:BINV.0000041562.31023.42.

34. Horsák, M.; Lososová, Z.; Čejka, T.; Juřičková, L.; Chytrỳ, M. Diversity and biotic homogenization of urban land-snail faunas in relation to habitat types and macroclimate in 32 central European cities. PLoS ONE 2013, 8, e71783. doi:10.1371/journal.pone.0071783.

35. Frankie, G.W.; Thorp, R.W.; Schindler, M.; Hernandez, J.; Ertter, B.; Rizzardi, M. Ecological Patterns of Bees and Their Host Ornamental Flowers in Two Northern California Cities. J. Kansas Entomol. Soc. 2005, 78, 227-246. doi:10.2317/0407.08.1.

36. Scheper, J.; Reemer, M.; van Kats, R.; Ozinga, W.A.; van der Linden, G.T.; Schaminee, J.H.; Siepel, H.; Kleijn, D. Museum specimens reveal loss of pollen host plants as key factor driving wild bee decline in The Netherlands. Proc. Natl. Acad. Sci. USA 2014, 111, 17552-17557. doi:10.1073/pnas.1412973111.

37. Geslin, B.; Gauzens, B.; Thébault, E.; Dajoz, I. Plant pollinator networks along a gradient of urbanisation. PLoS ONE 2013, 8, e63421. doi:10.1371/journal.pone.0063421.

38. Grundel, R.; Jean, R.P.;Frohnapple, K.J.; Glowacki, G.A.; Scott, P.E.;Pavlovic, N.B. Floral and nesting resources, habitat structure, and fire influence bee distribution across an open-forest gradient. Ecol. Appl. 2010, 20, 1678-1692. doi:10.1890/08-1792.1.

39. Williams, N.M.; Kremen, C. Resource distributions among habitats determine solitary bee offspring production in a mosaic landscape. Ecol. Appl. 2007, 17, 910-921. doi:10.1890/06-0269.

40. Zurbuchen, A.; Landert, L.; Klaiber, J.; Müller, A.; Hein, S.; Dorn, S. Maximum foraging ranges in solitary bees: Only few individuals have the capability to cover long foraging distances. Biol. Conserv. 2010, 143, 669-676. doi:10.1016/j.biocon.2009.12.003. 